\title{
Immunoinflammation and Elevated Serum Procalcitonin In Patients with Resistant Strain Mycobacterium Tuberculosis in Benin Metropolis
}

\section{Ibeh Nnanna Isaiah}

Health Services Department, University of Benin, Nigeria

*Corresponding author: Ibeh Nnanna Isaiah, Health Services Department, University of Benin, Nigeria, Tel: 08034834189; E-mail: andreibeh@gmail.com

Rec Date: July 18, 2014, Acc date: August 27, 2014, Pub date: August 29, 2014

Copyright: (C) 2014 Isaiah IN. This is an open-access article distributed under the terms of the Creative Commons Attribution License, which permits unrestricted use, distribution, and reproduction in any medium, provided the original author and source are credited.

\begin{abstract}
Background: The utility of serum procalcitonin (PCT) for differentiating pulmonary tuberculosis (TB) from bacterial acquired pneumonia (AP) in Benin Metropolis (Nigeria), a country with an intermediate TB burden.

Aim: To determine the bacterial acquired Pnuemonia from Mycobacterium tuberculosis associated pneumonia with the aid of procalcitonin levels Methods: We conducted a prospective study, enrolling 170 participants with suspected AP in a community-based referral hospital. A clinical assessment was performed before treatment, serum and PCT were measured. The test results were compared to the final diagnoses.

Results: Of the 170 patients, 98 had bacterial acquired pneumonia and 52 had pulmonary TB. The median PCT level was $0.528 \mathrm{ng} / \mathrm{mL}$ (range, 0.01 to 27.75 ) with bacterial acquired pneumonia and $0.042 \mathrm{ng} / \mathrm{mL}$ (range, 0.01 to 0.87 ) with pulmonary TB $(p<0.001)$. No difference was detected in the discriminative values of PCT $(p=0.733)$.

Conclusions: The concentrations of PCT differed significantly in patients with pulmonary TB and bacterial acquired Pneumonia. The high sensitivity and negative predictive value for differentiating pulmonary TB from bacterial acquired pneumonia suggest a supplementary role of PCT in the diagnostic exclusion of pulmonary TB from bacterial AP in areas with an intermediate prevalence of pulmonary TB.
\end{abstract}

Keywords: Pneumonia; Acquired; Procalcitonin; Tuberculosis; Serum

\section{Introduction}

In countries with a high tuberculosis (TB) burden, Mycobacterium tuberculosis is a frequent cause of community-acquired pneumonia (CAP) [1-4], and the differential diagnosis of TB from common bacterial pneumonia is difficult. The varying clinical and radiographic presentation of CAP and TB according to patient age and comorbidity and the low sensitivity of acid-fast bacillus microscopy make it even more difficult to distinguish TB from common bacterial pneumonia [5-7]. Therefore, an adjunct diagnostic method that can determine whether CAP is caused by pulmonary TB or other bacterial pathogens would have a clinical role in terms of isolating patients with $\mathrm{TB}$ and administering appropriate anti-TB medication or antibiotic treatment at an early stage.

Acquired pneumonia (AP) is a major cause of hospital admission and the most important infectious cause of death [1]. A rapid diagnosis and appropriate antibiotic treatment are essential to reduce the morbidity and mortality from AP.

PCT (Procalcitonin) a 116 amino acid protein is a biomarker of severe systemic infectious bacterial disease [8-11]. Recently, PCT has also been introduced as a promising alternative to CRP in guiding the antibiotic treatment of CAP and acute exacerbations of chronic obstructive pulmonary disease $[12,13]$ based on the ability of PCT to discriminate between patients with or without bacterial infection. In addition, PCT does not appear to be significantly elevated in patients with pulmonary TB [14-16], making it an attractive potentially rapid diagnostic method for differentiating pulmonary TB from bacterial AP.

Therefore, we investigated the utility of serum PCT for differentiating pulmonary $\mathrm{TB}$ from other bacterial AP in Benin Metropolis (Nigeria), a country with an intermediate TB burden.

\section{Patients and Method}

\section{Patients}

Of the 200 eligible patients, 30 were excluded because the final diagnosis was inconclusive or they had other diagnoses, such as pulmonary embolism, acute exacerbation of interstitial lung disease, or non-small cell lung cancer. One hundred and seventy patients were classified with pulmonary TB or bacterial CAP. None of the patients in this study was HIV-positive.

Patients were recruited between April 2013 and April 2014 after the study protocol had been approved by the Ethics Review Committee. Adult patients who visited the emergency department or outpatient clinic with respiratory symptoms and chest radiograph abnormalities were eligible for enrollment in this study.

Patients were considered to have pulmonary TB when $M$. tuberculosis was cultured from their sputum or lavage fluid, and the concentration of adenosine deaminase in the effusion was $>65 \mathrm{IU} / \mathrm{dL}$ in lymphocyte-predominant exudative pleural effusions combined with a lung parenchymal lesion. Bacterial CAP was diagnosed when the subjects had clinical signs of pneumonia and a new infiltrate on 
Citation: Isaiah IN (2014) Immunoinflammation and Elevated Serum Procalcitonin In Patients with Resistant Strain Mycobacterium Tuberculosis in Benin Metropolis. J Med Microb Diagn 3: 154. doi:10.4172/2161-0703.1000154

Page 2 of 4

chest X-ray, and these resolved completely with antibiotic treatment and cultures of sputum or lavage fluid were negative for $M$. tuberculosis during follow-up. For the microbiologic evaluation of the patients with AP, sputum Gram stains and cultures was performed, two blood cultures, and urinary antigen assays to detect Legionella pneumophila and Streptococcus pneumoniae.

Additionally, demographic data, a white blood cell (WBC) count and differential, and the Pneumonia Patient Outcomes Research Team (PORT) [17] score were collected. The results of these tests were compared to the final diagnostic group scores.

\section{Methods}

The PCT level was measured using a monoclonal immunoluminometric assay (LIA PCT sensitive; BRAHMS Diagnostica, Berlin, Germany). After separating the serum, it was aliquoted and frozen at $-70^{\circ} \mathrm{C}$ until analyzed. The functional assay sensitivity for PCT with a $20 \%$ inter-assay variation coefficient was $0.05 \mathrm{ng} / \mathrm{mL}$.

\section{Statistics}

Differences between the two groups were tested using the nonparametric Mann-Whitney $U$-test for continuous variables. Pearson's $\chi 2$ test or Fisher's exact test was used for categorical variables, and the Spearman rank correlation coefficient was calculated. Optimal cutoffs for predicting pulmonary TB or bacterial AP were investigated using receiver-operating characteristics (ROC) analysis, and the diagnostic accuracy was assessed from the area under the ROC curves (AUCs). A $p<0.05$ was regarded as statistically significant, and analyses were performed using SPSS version 15.0 (SPSS Inc., Chicago, IL, USA).

\section{Results}

Of the 170 patients who met the inclusion criteria, 98 had bacterial AP and 52 had pulmonary TB. The median age of the bacterial AP and pulmonary TB groups was 68 years (range, 18 to 88 ) and 46 years (range, 18 to 82 ), respectively. The responsible pathogen was determined in 42 patients (24.7\%) with bacterial AP.

Fourty eight (93\%) with pulmonary TB had positive respiratory specimen cultures for $M$. tuberculosis. The patients' demographic characteristics, symptoms, and laboratory results are compared in Table 1.

The respective median PCT level was $0.528 \mathrm{ng} / \mathrm{mL}$ (range, 0.013 to 27.754 ) and $0.042 \mathrm{ng} / \mathrm{mL}$ (range, 0.01 to 0.873$)(p<0.001)$. A significant positive correlation was detected with the PCT concentrations $(\mathrm{r}=0.648, p=0.01)$.

\section{Diagnostic accuracy for discriminating TB from bacterial AP}

Discriminative value of 0.857 (95\% confidence interval [CI], 0.778 to 0.936 ), and the PCT concentration had a discriminative value of 0.872 (95\% CI, 0.792 to 0.951 ). No difference was found in the discriminative value of PCT $(p=0.733)$. At a cutoff value of 12.5 $\mathrm{mg} / \mathrm{dL}$, the PCT concentration had a sensitivity of $93.1 \%$ and a specificity of $59.6 \%$ (Table 2).

\section{Discussion}

The results of this study are suggestive that PCT can help to discriminate between pulmonary $\mathrm{TB}$ and other common bacterial AP in a setting of intermediate TB prevalence. Significantly lower PCT serum concentrations were found with pulmonary $\mathrm{TB}$ compared to the other bacterial AP in the initial diagnosis stage. About 46,000 cases of TB are newly diagnosed annually in South Korea [18], and the rapid, accurate differential diagnosis of TB from common bacterial AP has important public health implications for the isolation care of patients with $\mathrm{TB}$ and early appropriate anti-TB medication or antibiotic treatment.

\begin{tabular}{|c|c|c|}
\hline $\begin{array}{l}\text { Bacterial pneumonia } \\
(n=98)\end{array}$ & $\begin{array}{l}\text { Tuberculosis } \\
(n=52)\end{array}$ & $p$ value \\
\hline \multicolumn{3}{|l|}{ Demographic characteristics } \\
\hline Age, yr 68 (18-88) & $46(18-82)$ & $<0.001^{*}$ \\
\hline Sex, male/female $36 / 21$ & $18 / 12$ & $0.77 \dagger$ \\
\hline History of tuberculosis 14 (24.6) & $6(20.0)$ & $0.63 \dagger$ \\
\hline \multicolumn{3}{|l|}{ Symptoms } \\
\hline Cough 62 (63.2) & $48(93.0)$ & $0.10 \dagger$ \\
\hline Sputum 48 (84.2) & $22(73.3)$ & $0.22 \dagger$ \\
\hline Fever 52 (91.2) & $15(50.0)$ & $<0.001 \dagger$ \\
\hline Dyspnea 34 (59.6) & $12(40.0)$ & $0.08 \dagger$ \\
\hline Night sweats $0(0)$ & $7(23.3)$ & $<0.001 \ddagger$ \\
\hline Weight loss 1 (1.8) & $8(26.7)$ & $0.001 \ddagger$ \\
\hline Chest pain 11 (19.3) & $9(30.0)$ & $0.30 \dagger$ \\
\hline \multicolumn{3}{|l|}{ Laboratory test } \\
\hline White blood cell, $\times 10^{3} / \mu \mathrm{L} 15.21(2.30-39.92)$ & $8.38(5.07-22.99)$ & $<0.001$ \\
\hline Neutrophils, $\times 10^{3} / \mu \mathrm{L} 11.06(1.70-37.92)$ & $5.85(3.07-20.23)$ & $<0.001^{*}$ \\
\hline Monocyte, $\mu \mathrm{L} 503$ (0-1210) & $535(253-5009)$ & $0.053^{*}$ \\
\hline Procalcitonin, ng/mL 0.528 (0.013-27.754) & $\begin{array}{l}0.042 \\
(0.01-0.873)\end{array}$ & $<0.001^{*}$ \\
\hline Upper lobe dominance 18 (28.1) & $23(76.7)$ & $<0.001 \dagger$ \\
\hline Cavitary lesion $0(0)$ & $11(36.7)$ & $<0.001 \mp$ \\
\hline Effusion 11 (19.3) & $9(30.0)$ & $0.26 \dagger$ \\
\hline PORT score 94 (18-187) & $76.4(10-126)$ & $<0.001^{*}$ \\
\hline \multicolumn{3}{|l|}{$\begin{array}{l}\text { Values are presented as number (\%) or } \\
\text { median (range). }\end{array}$} \\
\hline $\begin{array}{l}\text { PORT, Pneumonia Patient Outcomes } \\
\text { Research Team. }\end{array}$ & & \\
\hline \multicolumn{3}{|l|}{ * Mann-Whitney U-test. } \\
\hline $\begin{array}{l}\text { † Pearson } \mathrm{x} 2 \text { test. } \\
\text { † Fisher's exact test. }\end{array}$ & & \\
\hline
\end{tabular}

Table 1: Patients and Laboratory diagnosis 
Discriminating pulmonary TB from bacterial AP is frequently impossible based on patient history, physical examination, and radiographic findings. Therefore, PCT might have a role in the diagnostic algorithm as rapid, noninvasive tests.

\begin{tabular}{|l|l|l|l|l|}
\hline & Sensitivity & Specificity & $\begin{array}{l}\text { Positive } \\
\text { predictive value }\end{array}$ & $\begin{array}{l}\text { Negative } \\
\text { predictive } \\
\text { value }\end{array}$ \\
\hline $\begin{array}{l}\mathrm{PCT}, \\
\mathrm{ng} / \mathrm{mL}\end{array}$ & & & & \\
\hline$<0.1$ & 86.2 & 78.9 & 67.6 & 91.8 \\
\hline$<0.25$ & 93.1 & 59.6 & 54.0 & 94.4 \\
\hline$<0.5$ & 93.1 & 50.9 & 49.1 & 93.5 \\
\hline$<1.0$ & 100.0 & 31.6 & 42.6 & 100.0 \\
\hline
\end{tabular}

Table 2: Diagnostic validity of procalcitonin (PCT) in differentiating pulmonary tuberculosis from bacterial acquired pneumonia according to the different value

There was no difference observed in the discriminating power of PCT for differentiating pulmonary TB and other bacterial infections in this study. PCT has also been investigated as a predictor of bacterial infection and is considered a more accurate marker of various bacterial infections $[9,19]$. Therefore, the absence of a difference of PCT in our study should be considered in light of several factors. First, the low yield of a causative pathogen in bacterial AP (24.7\%) suggests the possibility of including bacterial AP with an atypical etiology, such as Mycoplasma pneumoniae, Chlamydia pneumoniae, and respiratory viruses. These atypical pathogens produce lower PCT levels than classical bacterial pneumonia such as pneumococcal pneumonia $[20,21]$. Second, because the hospital in which this study was conducted is a secondary referral hospital, although it is a communitybased hospital, more than 24 hours had passed from the onset of symptoms to the time some patients visited the hospital. The variable time interval from the onset of symptoms before evaluating PCT might have affected the results because of the kinetics of each inflammatory marker $[22,23]$.

\section{Conclusion}

In conclusion, serum PCT concentrations differed significantly in patients with pulmonary TB and those with bacterial AP at the initial diagnosis stage. The high sensitivity and negative predictive value for differentiating the diagnosis of pulmonary TB from bacterial AP suggest a supplementary role for PCT in the diagnostic exclusion of pulmonary $\mathrm{TB}$ from bacterial $\mathrm{AP}$ in areas with an intermediate prevalence of active pulmonary TB.

\section{Acknowledgement}

We are indebted to the intensive care unit nursing staff for their invaluable contribution to the management of the neonates and also the National Academy for the Advancement of Science, Nigeria, for their financial contribution and academic tutelage.

\section{References}

1. Marrie TJ (1994) Community-acquired pneumonia. Clin Infect Dis 18: 501-513.
2. Ishida $\mathrm{T}$ (2000) Etiology of community-acquired pneumonia among adult patients in Japan. Jpn J Antibiot 53 Suppl B: 3-12.

3. Scott JA, Hall AJ, Muyodi C, Lowe B, Ross M, et al. (2000) Aetiology, outcome, and risk factors for mortality among adults with acute pneumonia in Kenya. Lancet 355: 1225-1230.

4. Liam CK, Pang YK, Poosparajah S (2006) Pulmonary tuberculosis presenting as community-acquired pneumonia. Respirology 11: 786-792.

5. Kiyan E, Kilicaslan Z, Gurgan M, Tunaci A, Yildiz A (2003) Clinical and radiographic features of pulmonary tuberculosis in non-AIDS immunocompromised patients. Int J Tuberc Lung Dis 7: 764-770.

6. Perez-Guzman C, Torres-Cruz A, Villarreal-Velarde H, Salazar- Lezama MA, Vargas MH et al. (2001) Atypical radiological images of pulmonary tuberculosis in 192 diabetic patients: a comparative study. Int J Tuberc Lung Dis 5: 455-461.

7. Lieberman D, Lieberman D, Schlaeffer F, Porath A (1997) Communityacquired pneumonia in old age: a prospective study of 91 patients admitted from home. Age Ageing 26: 69-75.

8. Uzzan B, Cohen R, Nicolas P, Cucherat M, Perret GY (2006) Procalcitonin as a diagnostic test for sepsis in critically ill adults and after surgery or trauma: a systematic review and meta-analysis. Crit Care Med 34: 1996-2003.

9. Simon L, Gauvin F, Amre DK, Saint-Louis P, Lacroix J (2004) Serum procalcitonin and C-reactive protein levels as markers of bacterial infection: a systematic review and meta-analysis. Clin Infect Dis 39: 206-217.

10. Müller B, Becker KL (2001) Procalcitonin: how a hormone became a marker and mediator of sepsis. Swiss Med Wkly 131: 595-602.

11. de Werra I, Jaccard C, Corradin SB, Chioléro R, Yersin B, et al. (1997) Cytokines, nitrite/nitrate, soluble tumor necrosis factor receptors, and procalcitonin concentrations: comparisons in patients with septic shock, cardiogenic shock, and bacterial pneumonia. Crit Care Med 25: 607-613.

12. Stolz D, Christ-Crain M, Bingisser R, (2007) Antibiotic treatment of exacerbations of COPD: a randomized, controlled trial comparing procalcitonin-guidance with standard therapy. Chest 131: 9-19.

13. Christ-Crain M, Stolz D, Bingisser R, Müller C, Miedinger D, et al. (2006) Procalcitonin guidance of antibiotic therapy in community-acquired pneumonia: a randomized trial. Am J Respir Crit Care Med 174: 84-93.

14. Polzin A, Pletz M, Erbes R, Raffenberg M, Mauch H, et al. (2003) Procalcitonin as a diagnostic tool in lower respiratory tract infections and tuberculosis. Eur Respir J 21: 939-943.

15. Lawn SD, Obeng J, Acheampong JW, Griffin GE (1998) Serum procalcitonin concentrations in patients with pulmonary tuberculosis. Trans R Soc Trop Med Hyg 92: 540-541.

16. Schleicher GK, Herbert V, Brink A, Martin S, Maraj R, et al. (2005) Procalcitonin and C-reactive protein levels in HIV-positive subjects with tuberculosis and pneumonia. Eur Respir J 25: 688-692.

17. Fine MJ, Auble TE, Yealy DM, Hanusa BH, Weissfeld LA, et al. (1997) A prediction rule to identify low-risk patients with community-acquired pneumonia. N Engl J Med 336: 243-250.

18. World Health Organization (2007) Global Tuberculosis Control: Surveillance, Planning, Financing (WHO/HTM/TB/2007.376). WHO Report Geneva.

19. Müller B, Harbarth S, Stolz D, Bingisser R, Mueller C, et al. (2007) Diagnostic and prognostic accuracy of clinical and laboratory parameters in community-acquired pneumonia. BMC Infect Dis 7: 10.

20. Hedlund J, Hansson LO (2000) Procalcitonin and C-reactive protein levels in community-acquired pneumonia: correlation with etiology and prognosis. Infection 28: 68-73.

21. Moulin F, Raymond J, Lorrot M, Marc E, Coste J, et al. (2001) Procalcitonin in children admitted to hospital with community acquired pneumonia. Arch Dis Child 84: 332-336.

22. Pepys MB, Hirschfield GM (2003) C-reactive protein: a critical update. J Clin Invest 111: 1805-1812. 
Citation: Isaiah IN (2014) Immunoinflammation and Elevated Serum Procalcitonin In Patients with Resistant Strain Mycobacterium Tuberculosis in Benin Metropolis. J Med Microb Diagn 3: 154. doi:10.4172/2161-0703.1000154

Page 4 of 4

23. Dandona P, Nix D, Wilson MF, Aljada A, Love J, et al. (1994)

Procalcitonin increase after endotoxin injection in normal subjects. J Clin Endocrinol Metab 79: 1605-1608. 